\title{
CREATING A POPULIST POLITICAL FIGURE: AN INDONESIAN CASE
}

\author{
Ekmel GEÇER \\ University of Health Sciences, Turkey \\ ekmel.gecer@sbu.edu.tr \\ https://orcid.org/0000-0003-3367-2236 \\ Nur FADİLLAH \\ Master Candidate, University of Sakarya, Turkey \\ nur.fadillah@ogr.sakarya.edu.tr \\ https://orcid.org/0000-0002-9464-4522
}

\begin{abstract}
This paper, in comparison with a Western/European approach, aims to briefly explain the role of the media as a tool for creating and rising a political image in Indonesia. In the presidential election of 2014, Indonesia had two candidates. One of them named Mr. Joko Widodo also known as Jokowi. During his campaigns, he offered policies that try to respond to civil demands while his physical appearance also claimed to be a cool one by his supporters. Detik.com, as one of the electronic mediums, uses this circumstance to generate the news about Jokowi's personality positively for him to gain public sympathy. Methodologically this study uses discourse analysis and documentation as the data collecting technique. Therefore, we used descriptive qualitative approach with the analysis of Teun van Dijk's critical discourse, specifically the dimensions of the text. The main research platform here is detik.com, an online news site allegedly pro-Jakowi. We have here taken 50 news items as the analysis unit on the period time started from 5 June to 4 July 2014. The results of this study indicate that detik.com as an Indonesian media course tries to support and represent Jokowi's political image as a populist and ideal figure who could symbolize the public interest in the Republic of Indonesia.
\end{abstract}

Keywords: Media, Populism, Political image and psychology, Indonesia.

\section{POPÜLİST BİR POLITTIK FİGÜR YARATMAK: BİR ENDONEZYA ÖRNEĞİ}

\section{ÖZ}

Bu çalışma, bir Avrupa/Batı yaklaşımı kıyaslamasıyla, Endonezya'da medyanın politik imaj yaratma ve bu imajı yüceltmedeki rolünü kısaca açıklamayı amaçlamaktadır. 2014 başkanlık seçimlerinde Endonezya'da iki aday yarıştı. Jokowi olarak da bilinen Joko onlardan biriydi. Kampanyası süresince toplumsal ihtiyaçlara cevap vereceğini söyleyen Jokowi, destekçileri tarafından da karizmatik bir lider olarak nitelendiriliyordu. Elektronik ortamlardan biri olan Detik.com Jokowi'nin kamusal sempati kazanması için onunla ilgili pozitif haberler yapıyordu. Elinizdeki çalışmada, veri toplama yöntemi olarak söylem analizi ve dokümantasyon kullanılmıştır. Bu çerçevede betimsel nitel bir yaklaşımla Van Dijk'in özellikle metinsel bağlamda olan eleştirek söylem analizi kullanılmıştır. Çalışma evreni olarak Jokowi destekçisi olduğu iddia edilen detik.com haber sitesi seçilmiştir. Buradan elde edilen 50 haber metni 5 Haziran ve 4 Temmuz 2014 aralığından alınmıştır. Çalışmanın sonuçları, Endonezya medyasının (detik.com), Jokowi'nin politik imajını desteklemek ve onu Endonezya Cumhuriyeti halkının gözünde ideal figür olarak temsil etmek için daha açık ve yoğun bir haber içeriğine sahip olduğunu göstermiştir.

Anahtar Kelimeler: Medya, Popülizm, Politik imaj ve psikoloji, Endonezya. 


\section{INTRODUCTION}

There is no doubt that almost the entire literature talks about the close relationship between media and politics. This connection in further terms somehow influences political communication strategies too. While media or journalists need the politicians of daily news as a source which has become a minuteby-minute news hole on live television and the web. On the politicians' side, they need media or journalists to help them get the headlines and airtime they crave (Willis, 2007: XII), particularly in close election campaigns. In the basic words, politicians use the media to mobilize the public support they need to win and for the media or journalists, they utilize the politicians to produce stories that attract the audiences (Zaller, 1999: 2). Besides, the citizens access the news media to see, hear and read about the latest political event and opinion of public figures. Media, however, in the democratic term have responsibility for providing the political information necessary to allow citizens to make political decisions and give their votes based on informed choice, about the extent to which the government has kept its promises, and about how rival contenders will act if elected or reelected in the government. The most important, the reasoned choice required that the political information flowing to the citizens must be impartial in the sense of not being biased in favor of any of the contestants for office (Mughan, 2010: 478).

As a matter of fact, the media as a fourth estate or power in the democracy after judiciary, executive, and legislature have been criticized due to the emergence of the media organisations or owners who are involved in politics so that they can influence the decision in making news. The authority of the media organisations in news production is often exaggerate and resulted the standardisation of news format. It causes the news values to be distorted when it is disseminated to the citizens and even that causes the freedom of journalists to be bound in making or broadcasting controversial news (Craig, 2004: 17). In addition, the presence of media power and the involvement of the media organisation give the opportunity to other power groups to use the media as an arena to control the distribution of information in public life. The aims of this activities are to manipulate opinions for business and political meaning (Ekstrom, 2017: 45). Not surprisingly, by many stated that the media is often heard in a witty remark, "the power of the press belongs to those who own one" (Willis, 2007: 145).

In July 2014, the media had an immense power on the Indonesian presidential election. Most of the media in the level of national exercised their roles to enliven the democratic process. Other than as media organisations and politicians involved in the election to back up each of their presidential candidate whiz in the political arena (Aji, 2018: 7). In the election, there were two leading presidential candidates: Joko Widodo, popularly called Jokowi, and Prabowo Subianto, shortly called Prabowo. Those candidates totally have different background information. While Jokowi is from civilian and the other hand, Prabowo is from a military. Although they have divergent background information but in the political campaign they presented as populist leaders in their own way. Instance, Jokowi's populism was pragmatic, moderate, and inclusive. Conversely, Prabowo's populist inclined with the idea of nationalism. His populist seems similar to one of the leaders in Venezuela, Hugo Rafael Chavez (Mietzner M., 2014: 115). In the end, the General Election Commission (KPU) announced on 22 July 2014 that Jokowi had 53.15\% vote from 33 total of Indonesia's provinces and his opposition Prabowo got $46.85 \%$ vote (BBC, 2014). Jokowi's victory as a civilian is very interesting to be analysed in his appearance in the media and political communication.

Jokowi, since he was elected as governor of Jakarta and then after 2 years decided to enter the president election market, he has never been separated from the reporting of media activities. His personal characters such as down to earth, informal language, the face that look villager with medok accents of Javanese, often dressed long sleeve white shirt and black trousers, and ate at roadside food stalls are made as a political communication strategy for a great news on media. Even some of the national media reported his existence obsessively in daily news (Aspinall \& Mietzner, 2014: 351). His figure is incringsingly more popular and his image framed as a populist after he did several blusukan (impromptu visit) programs which this program are kind of different personal political communication campaign model by visiting particular places such as kampungs, traditional markets, and slums. He communicated

Research Article - This article was checked by iThenticate

Copyright (C) The Turkish Online Journal of Design, Art and Communication 
with people to hear their problems and aspirations. Hence, it made him seen as distinguished and unique candidate and has become his personal political communication in order to gain public support and sympathy. Jokowi's image toward his political communication is widely reported whether by national media or online media (Hamid, 2014: 96). As noted by Kutseva, it is impossible if the function of the media, only as a mediator to serve between political institutions and citizens, because to create image politics need the existence and influence of the media (Kutseva, 2011: 147). On the other hand, behind his popularity on the media, there are considerations that Jokowi as a person who lack of capability and experience in the country's affairs and lack of proficiencies including English language. Even to make decisions, he mostly consulted to Megawati Soekarnoputri, a Chairman of Indonesian Democratic Party of Struggle (PDI-P) (Prokurat, 2014: 198). As a member of PDI-P and his closeness and loyalty to Megawati, make Jokowi labeled as a "puppet" with Megawati pulling the strings (Aspinall \& Mietzner, 2014: 356). In other words, Jokowi as a leader has not been able to get out of the status of party officers.

One of the online mainstream media detik.com, a big company under CT corps owned by Chairul Tanjung, serves news every hour and second which is has paid attention in the Indonesia presidential election in 2014 and has intervention in the intensity of Jokowi's image framing in news during campaign. According to Alexa (Alexa, 2018) data on 11 December 2018, detik.com becomes the $6^{\text {th }}$ ranking sites that have been visiting by people after google.com, google.co.id, youtube.com, yahoo.com, and kompas.com in Indonesia and become 113th ranking in the world. Every day, detik.com has visitors from about 3 million users to access news such as politic, finance, health, food and so on. It indicates that detik.com as an online media could give significant influence related to news in politic for public opinion (Prabawati, 2017). Hence, it is interesting to be analyzed the involvement of the online news site like detik.com, as one of the national online media, in the news about the presidential candidates toward the political campaign.

Based on the explanation above and the previous research by Ghanes Eka Putra with the title "'Bingkai Media Terhadap Pemberitaan Capres Jokowi Pada Pilpres 2014 (Analisis Framing Media Online Kompas.com dan Detik.com)" which focus on the comparison of two online news sites such as kompas.com and detik.com that reporting and constructing Jokowi's image during the presidential campaign, he stated that the kompas.com had domination on publishing Jokowi's positive image than his negative side (Putra, 2014: 6). Conversely, detik.com seems to be neutral on Jokowi's image. Yet this study suggests the differences related to the construction of Jokowi's image by detik.com. Therefore, the research interested in deeply analyzing how detik.com constructed Jokowi's image during the presidential campaign from June to July 2014 to influence public opinion and tries to approach the Indonesian election through a European political campaigning strategy.

\section{POLITICS AND MEDIA IN INDONESIA: A CHRONOGICAL VIEW}

Over the last three decades, the development of the mass media in Indonesia has been improving progressively. Form being controlled, minitored, censored, and even prohibeted that not in line with the government interests, to be free and unrestrained (Mukrimin M. , 2013: 57). Up to now, the politics and media have been colored the process of maturing democracy in Indonesia. To figure out what extent media and politics influence the process of democracy in Indonesia, first, let us come to the definition of media and politics. According to dictionary of media and communication, media are systems, devices, or assorted forms of mass communication such as newspapers, magazines, radio stations, television channels, web site, and so on, that can transmit the information of any means (Danesi, 2013: 412). The scholar, Geoffrey Craig defines media is a comprehensive term that can be interpreted as enterprises, technologies, policy, journalists, news, movie, advertisements, musics, radio, and the internet (Craig, 2004: 3).

Furthermore, politics is power and influence that interconnected each other between the government's and people's interests. Politics is also kind of the process where the government has authority to choose and seek the variety of collective goals which will later be implemented for people (Peters, 2004: 25).

Research Article - This article was checked by iThenticate

Copyright (C) The Turkish Online Journal of Design, Art and Communication 
Hans Morgenthau simply defines politics is the struggle for power (Morgenthau, 1948: 13). The relations between the media and politics is very essential in a functioning democracy. In spite of they have their own missions and duties, it does not mean they do not have a symbiotic interection, Simply, the politicians come to the citizens to ensure their actions with a political campaign so they can win the heart and get the trust from the people (Barner, 2011: 4). Besides, the media need politicians' image to attract the audiences on the news so they can access the political figüre. Then politicians need media as a platform to promote their positions (Morissan, 2017: 208).

Historically, since Indonesia became an independent country, the development of media has been shaped and influenced by various political leaders in which each of them have divergent ideologies from the Old Order (Guide Democracy), New Order (Developmentalism), transition period (Reformasi) up to the current regime (Mukrimin M. , 2013: 57). As noted by Rendro Dhani and friends (Dhani et al, 2015: 23), the role of the media in Old Order and New Order regime are closely used for propaganda and both regimes significantly control over the media. The role of the media in Old Order and New Order regime are closely used for propaganda and both regimes significantly control over the media. For examples if journalists were expressing political opinions which not in line and contrary to the interest of the government, they are directly arrested as political prisoners. And even if there were media outlite expose and criticize the government's performance, they clearly were banned. As a matter of fact, betwen 1963 and 1967, there were 163 newspapers were banned and thousands of madia workers were arrested and killed (Kakiailatu, 2007: 63). By the uprising in May 1998 in Indonesia, marked the end of New Order era and brought the fresh air for new democratic process which allow the freedom of the media and political communication. It was showed by 40 newly journalist associations were established, and the media sphere were finally free to distribute political information and media became as a platform for the discussion related political issues (Gazali, 2009: 127).

In indonesia, by the growing of the mass media, at the same time, also the growing of the media organisations or ownerships. This phenomenon, generarlly known as media conglomeration which media often owned privately and commonly the owners affiliate with political parties (Susilo, 2017: 43). It means the freedom of media that were influenced, controlled, and shaped by the previous government, now can be continued by media organisations. It can be said the journalists did not fully get their freedom after the May uprising. As noted by Anders C. Johansson (Johansson A. C., 2016: 22), Those media organisations are not only directrly controlled by key politicians in the transitional government. But also they are supporting politicians. The motives are to use the media as a channel for manipulation and propaganda by implementing agenda-setting, framing, and priming. Gennerally those theories also aimed to influence citizens during the political decision process. According to Eko Maryadi, the Chairman of the Independent Journalist Alliance stated during the 2014 presidential election, Indonesia is one of bad example countries in the Southeast Asia region in the term of media independence. The media organisations have practiced by interfering and promoting thier political interest blatantly (Pahdepie, 2015: 5).

Indonesia's presidential election in 2014 is one of the examples in the relations between media ownership and political sphere. There were two candidates in what this study has mentioned above: Jokowi and Prabowo. Those candidates authorized by the Indonesian Election Commission (KPU) to compete for the nation's Presidency. During the presidential campaign, two TV channels owned by conglomerates and also as politicians that endorsed each candidate. Particularly Metro TV owned by Surya Paloh endorsed Jokowi. Conversely, TV One owned by Aburizal Bakrie endorsed Prabowo Subianto. Both owners promoted news bias and intervention during the presidential election. The extent of political bias was showed by the Indonesian Broadcasting Commisson's (KPI) observations from 19-25 May 2014 which resulted those national TV channels competed and against each other to support their respective choice. For examples Metro TV channel, broadcasted the news about Jokowi for 184 times or 35, 577

Submit Date: 06.07.2020, Acceptance Date: 02.09.2020, DOI NO: 10.7456/11004100/004

Research Article - This article was checked by iThenticate

Copyright (C) The Turkish Online Journal of Design, Art and Communication 
seconds on the screen, while it broadcasted Prabowo in its channel for 110 times or 14, 561 seconds. In turn, TV One channel, endorse Prabowo Subianto 153 times amounting to 36,561 seconds, while Jokowi only appeared 77 times or 18,731 seconds. It is proven that Metro TV endorse Jokowi more than Prabowo and TV One endorse Prabowo more than Jokowi in the aired news (Asyari, 2015: 3).

The phenomenon above shows the media are used as proxies in the battle between the rival political group. The media ownerships have used their media power to shape public preferences about the presidential candidate. As long as the media utilized as a tool for political campaign in order to influence the citizen opinion, it is going to jeopardize for citizen's right toward information (Nugroho et al, 2012: 4). The significant control and intervention of the media by owner' and politicians' interests in the presidential elections are a highlight as a weakness in democratic process in Indonesia. In democratic term, the media are supposed to be independent and not take sides on each candidate. What Coronel noted (Coronel, 2003: 2) if the media organisations have good and decent financials, then media independence will be guaranted to be free from the intervention of media owners and politicians. When the media free from any intervention, it can operate in the competitive environment.

\section{IMAGE CONSTRUCTION IN THE NEW MEDIA ERA IN INDONESIA: POPULISM VERSUS FACTS}

The digital revolution has been dramaticaly changing and transforming the development of the media communication from the old to the new one. At the same time, it results the increasing of the public in access the information. The most important, political institution activities are mediated advanced by the technology of information and communication. As noted by Jamil (Jamil, 2018: 1), new media technologies have a powerful influence such as citizen can be able to access the information and monitor the government activities, a strategy for political campaign, reference the voters for candidates, distribute the political messages, and so on. What are exactly new media means? As Lister ( Lister et al, 2003: 13) point out, new media are the new way of production and distribution of the media content to the citizens. They also have transformed particularly in the operation system from traditional, include newspapers, television, radio, to modern one based on internet. Cambridge dictionary defines new media as products and services that provide information or entertainment using a computer or the internet, and not by traditional methods such as television and newspapers. In other words, modern ways of sharing information or providing entertainment, for example, the internet or smartphones (Cambridge, 2018).

In Indonesia, and also around the globe, the use and popularity of networking sites are increasing dramatically. According to the Indonesia Internet Service Provider Association (APJII), the percentage of internet penetration grows in 2010 that only 16 percent (42 million of 262 million people) becomes 54, 58 percent (143 million) in 2017 (APJII, 2017: 5). The increasing number in using internet connection makes Indonesia achieve the $5^{\text {th }}$ rank of the highest number of internet users in the world in 2017 after China, India, the United States, and Brazil (Stats, 2017). By increasing the internet penetration in Indonesia, it is also increasing the number of social media users. The internet has changed the dynamics of public engagement in democracy and political activities (Perbawani et al, 2018: 187). For the time being, the emergence of the internet and intensive use of new media make society more interactive and prominent in political discourses.

The online media, exactly the news media started developing in the 2000. As noted by one of the founders of detik.com, after the year 2000, the internet costs were falling, and it caused the number of ISPs were increasing. That was the turning point the media outlites expand their market from offline news to online news production. Since then and up to now, the citizens read the offline news as well as the online news. The development of the new media also changes the behavior the way the citizens enjoy the news. The citizens who are usually using the internet, they are only reading the headlines in the newspapers, then they read the full news through the internet. And may the citizen read the news

Research Article - This article was checked by iThenticate 
through the internet first and read the newspapers only if they have time to left to do it. For the media outline, the interesting headline of the news is very crucial strategy to promote the media content to attract the citizen and spread into the social media (Nugroho et al, 2012: 87). Up to now according to the Ministry of Communication and Informatics, there are 43 thousand online news portals. Yet only 100 online news portals verified by the Indonesia Press Council (Menkominfo, 2018). With the number of online news portals growing in Indonesia, it is easier for citizens, especially those using the internet to access the news.

After all, the old and new media have no huge differences. The difference is one uses the internet and the other does not. The process of the news production between conventional and modern media also is not has big different. So that is why, the online media might come to be new packaging for the same content in the advance of technology (Nugroho et al, 2012: 86). Daniela noted simply new media is a complement to the old media. They are interrelated and complement each other (Dimitrova et al, 2014: 97). In a study, Balbi analyzes the old and new media are not experiencing cleavage. Both are affecting each other and often indistinguishhable from one to another (Balbi, 2015: 245). The question is what if media owners who have political interests not only control the old media but also the new media in Indonesia presidential election? Furtunato and Martin stated that the media organizations can be able to control the framing when they influence the media content decision making process. If the mass madia have the function of selecting and framing message, not much different, new media also have the same function (Fortunato \& Martin, 2017: 130). As a matter of fact, in the news reports, framing can influence how it is understood by citizens and framing influence how the citizens think about it (Strömberg, 2015: 176).

Whether the old media or new media have been becoming a strategic plan for political purpose like presidential candidates. During the campaign they build a good figure to influence the voter enggagement. The dissemination of the information related to the presidential candidate issues through the old media (newspapers, television, radio, etc) and new media (online news sites, facebook, twitter, instagram, etc) has affected how the information is being processed. What this study mentioned above, the old media and new media are not have huge different. The content of the news is same and just only the packaging is different. Hence, the information from the online media through the social media can be reproduced as news. The news that consumed by citizens can give impact voter preference. Social media has a fundamental role in raising the political candidates who are newcomer and unpopular into becoming popular candidates and serious contenders in the presidential elections (Johansson, 2016: 36).

The populist figure of Jokowi and his political strategy, blusukan as political communication, could gain political support from the middle and the grassroots level. Hara claimed (Hara, 2018: 108) that the citizens who support the Jokowi populism are generally experience the difficulties in their life. His promises for the citizens during the campaign put the hope for the citizens in order to raise the standard of living for better life. For examples, improve the bureaucracy, form a clean government, provide free health and education programs and so on. The Jokowi's political communication made him popular in the media and become as media darling.

In Kurt Weyland's formulation (Aspinall, 2015: 2), populism is a political strategy that used by a personality leader to seek and exercise power based on direct support from a large number of citizens which mostly unorganized followers. Majid Khosravinik defines (Khosravinik, 2017: 62), populism is an individual or political actor who understand about the media to mobilize the grassroots which have the same interests. In the context of populism, Jokowi has been using the blusukan strategy to directly communicate to society and bring populism programs in his campaign to appeal to vote from. The blusukan had a direct benefit for online news sites. They help Jokowi became the politician most regularly covered in the news. As a result, he led all nationwide polls as the most popular candidate for president throughout 2013 and 2014 (Tapsell, 2015: 43).

Research Article - This article was checked by iThenticate

Copyright (C) The Turkish Online Journal of Design, Art and Communication 


\section{METHODOLOGY}

This study uses a quantitative method of critical discourse analysis. According to Teun A. Van Dijk "critical discourse analysis is a discourse analytical research that primarily studies the way social-power abuse and inequality are enacted, reproduced, legitimated and resisted by text and talk in the social and political context" (Dijk T. A., 2015: 466). The analaysis of the problem for this study was two approaches: empirical sociological approaches and critical approaches. The empirical sociological method approaches discourse in a speech context which is at the end somehow linked to the context of the situation (Asher and Simpson 1994: 940). On the other hand, in the empirical sociological approach, the discourse is assessed from an external angel. From this external perspective, discourse can be studied in terms of its relation to three issues the speaker, the issue, which is discussed, and the target whom the speaker is talking to.

For data analysis we used the van Dijk critical discourse analysis paradigm to examine the construction of news texts in newspapers. Van Dijk (1988) divided the discourse analysis into three dimensions: the text dimension, the dimension of social cognition, and the dimension of social context/practice. However, we here focused on the study of the dimensions of the text to describe and interpret the news text: the structure of the text including the words, sentences, and paragraphs. Yet, a text for a specific analysis consists of three structures/levels: macrostructure (meaning), superstructure (text structure, framework the text arrangmenet: introduction, text order, conclusison), and microstructure (the meaning that the text may point which could be excluded from the words, sentences, paragraphs within the whole text).

That is in fact why discourse analysis is oftenly used by journalism studies in relation to text analysis. The media, especially online sites in this era of technology development can produce the news as much as possible, even within a few minutes instead of the printed news that must be processed in a long time. The efficiency of producing the news from the new online sites could give a benefit for the political leader to gain voter's hearts in the presidential election.

In the Indonesia presidential campaign 2014, the online news sites were trying to produce the news and serve the public intensively related to the updating of political presidential candidates' activities. Besides, the readers also can consume the news easily with smartphones no matter where they are. Hence, that is one of the reasons why detik.com becomes an object of this study. And the other reason why this study has chosen this online news site because this site has become the sixth ranking that has been visited by the people after google.com, google.co.id, youtube.com, yahoo.com, and kompas.com in Indonesia. It indicates detik.com has a huge influence on the users when they read the news or get information published by detik.com on internet sites.

The media is one of the fourth estates that has power is not only can control the government but also can control the public at large through the information or news. In what have this study explained above the involvement of the political interest whether in the owner of the media outlet or political force toward the news content in the political campaign time would question the neutrality of media as a mediator between citizens and politicians. Hence, this critical discourse analysis is very important to analyze and see how the positive image of Jokowi as a populist leader is constructed by the media during the presidential campaign.

The influence of the news can get bigger when the users share it with the other users through new media online and the snowballing effect will occur by nature. Hence, detik.com becomes the prime source of this study to collect the data. This study takes 50 analysis unit from the site at the period time started on 5 June to 3 July 2014.

The title of the news will be the focus on this analysis because the title is representative of the content of the news and even can be seen as the main point of the news. These titles will be grouped into four. Firstly, the news about personal Jokowi's image construction. Secondly, the news about Jokowi's campaign promises and blusukan. Thirdly, the news about Jokowi's supporter from volunteers and

Research Article - This article was checked by iThenticate

Copyright (C) The Turkish Online Journal of Design, Art and Communication 
people from various jobs and levels. Lastly, the news about the survey and polls about Jokowi. So, this study will explore how the detik.com construct Jokowi's positive image in the presidential election.

\section{FINDING AND ANALYSIS}

Media in Indonesia tends to involve in political activities. There is no one media in Indonesia is released from political activities, event in the presidential elections. Most political candidates can increase their political image or popularity in media to be known by the public. Besides, the owners of the media also can take advantage of their coverage when plunging into the world of politics as a medium of political communication. There are several number of the owners of the media that come into political activities in Indonesia such as Hary Tanoe (the owner of MNC TV, RCTI, GLOBAL TV, INEWS TV, INDOVISION, SINDO News, Okezone, Global radio, and so on), Abu Rizal Bakrie (the owner of ANTV TV, TVOne, VIVA News, etc), Surya Paloh (the owner of Metro TV, Media Indonesia, etc), and Dahlan Iskan (Jawa Post, Fajar FM, etc) (Adam, 2018).

They can use their media to promote a political candidate in presidential elections or parties. Even they can increase the popularity of every presidential candidate which they support. For example, in the presidential election in 2014, Metro TV and TVOne used broadcast frequencies for certain groups or party-political interests to provoke the public. Hence, both received a strong reprimand from the ministry of communication and informatics (Asril, 2014). In Indonesia, many facts show that most of the media can not be neutral because the owners of the media are politicians or have a connection with the presidential candidate who needs news to make or support the presidential candidate to be known and introduced in the eyes of the public. The involvement of the media in politics in Indonesia is so deep and it is difficult to see their neutrality or choice not to enter the political sphere.

The mass media's partiality toward one of the presidential candidates does not only occur in the old media but also occurs in the new media. One of the examples is detik.com. Detik.com, in the presidential election 2014, tended to support one of the presidential candidates named Joko widodo. Detik.com had tried to construct the Jokowi's image positively in its headline news during the presidential campaign period. Detik.com is an online news site that has quite several readers. It was established on 30 May 1998 by four people such as Budiono Darsono (the former DeTik reporter), Yayan Sopyan (the former DeTik reporter), Abdul Rahman (the former Tempo reporter) and Didi Nugrahadi (Budiono's neighbor). But on 3 August 2011, CT Corp owned by Chairul Tanjung acquired $100 \%$ of detik.com shares. In July 1998 the detik.com site per day received 30,000 hits with around 2,500 users. Nine months later, in March 1999, hits per day increased seven-fold, to an average of 214,000 hits per day or 6,240,000 hits per month with 32,000 users (Unila).

In June 1999 , that number rose again to 536,000 hits per day with users reaching 40,000 . Finally, hits detik.com reaches 2.5 million more per day. In addition to the calculation of hits, detik.com still has other measurement tools that have so far been agreed upon as a measure that approaches how much potential a site has. Page view of detik.com now reaches 3 million per day. Now detik.com occupies the sixth highest position of alexa.com for all content in Indonesia after google.com, google.co.id, youtube.com, yahoo.com, and kompas.com in Indonesia (Alexa, 2019).

The main commissioner of detik.com is Drs. Raden Suroyo Bimantoro. He was a Chief of Police of the Republic of Indonesia under Abdurrahman Wahid (Gusdur) administration. He became the Chief of Police of the Republic of Indonesia started from 23 September 2000 to 21 July 2001 because he was dismissed by Gusdur (Billiocta, 2015) but he regained his position after Megawati Soekarnoputri replaced Gusdur as a president (Voaindonesia, 2001). Megawati is the chairman of Indonesia Democratic Party of Struggle who brings Jokowi starting from being a mayor in Solo city, a governor in Jakarta to a president in the Republic of Indonesia. It Indicates there was a tendency that detik.com had a role to construct Jokowi's positive image during the presidential campaign in 2014. Following the development of the news about Jokowi in detik.com, it would be known clearly that detik.com is an online news site media that tend to support Jokowi by uploading his image positively in the news.

Research Article - This article was checked by iThenticate

Copyright (C) The Turkish Online Journal of Design, Art and Communication 
The Turkish Online Journal of Design, Art and Communication - TOJDAC

ISSN: 2146-5193, October 2020 Volume 10 Issue 4, p373-388

Table 1. The news discourses which Jokowi as a leader

\begin{tabular}{|c|c|}
\hline Date & News in detik.com \\
\hline 5 June 2014 & $\begin{array}{l}\text { Pernah tinggal dibantaran kali, jokowi mengaku mengerti penderitaan rakyat } \\
\text { Having lived on a riverbank, Jokowi admitted that he understood people's suffering }\end{array}$ \\
\hline 10 June 2014 & $\begin{array}{l}\text { Dukungan dari Grass Root Luar Biasa karena Jokowi Merakyat } \\
\text { The support from grass root is extraordinary because Jokowi is low profile }\end{array}$ \\
\hline 11 June 2014 & $\begin{array}{l}\text { JK: Jokowi Jadi Wali Kota Dipilih Hampir } 100 \% \text {, Pasti Amanah } \\
\text { JK: Jokowi is almost } 100 \% \text { elected as a mayor, definitely a reliable person }\end{array}$ \\
\hline & $\begin{array}{l}\text { JK: Jokowi Imam Salat yang Baik, 'Kawan Sebelah' Belum Tentu } \\
\text { JK: Jokowi, good imam of prayer, the opponent is not necessarily good }\end{array}$ \\
\hline 13 June 2014 & $\begin{array}{l}\text { 'Kepanjangan Jokowi Ternyata Joko is We, Jokowi adalah Kita' } \\
\text { 'Jokowi name stands for Joko is We' }\end{array}$ \\
\hline & $\begin{array}{l}\text { Survei: Rakyat Masih Mengharapkan Pemimpin Jujur, Tegas Urutan Kedua } \\
\text { Survey: People still expect honest leader, assertiveness can be second place }\end{array}$ \\
\hline & $\begin{array}{l}\text { Jokowi: Kalau Jadi Presiden Saya di Kantor Sejam, Selebihnya di Kampung } \\
\text { Jokowi: If I were president I would be in the office for an hour, the rest I would be in village }\end{array}$ \\
\hline 18 June 2014 & $\begin{array}{l}\text { Joko Anwar: Jadikan yang Biasa Bekerja dengan Rakyat Pemimpin Kita } \\
\text { Joko Anwar: Make someone who usually works with the people as our leader }\end{array}$ \\
\hline & $\begin{array}{l}\text { Garin Nugroho: Saatnya Memilih Pemimpin yang Melayani Rakyat } \\
\text { Garin Nugroho: It is time to choose a leader who serves the people }\end{array}$ \\
\hline 19 June 2014 & $\begin{array}{l}\text { Jokowi: Fitnah Harus Kita Balas dengan Kebaikan } \\
\text { Jokowi: We must pay slander back with kindness }\end{array}$ \\
\hline 30 June 2014 & $\begin{array}{l}\text { Jokowi: Saya Mulai Hidup dari Miskin, Saya Bisa Rasakan Hidup Sulit Buruh } \\
\text { Jokowi: I started living from poverty, I can feel the difficult life of laborers }\end{array}$ \\
\hline 2 July 2014 & $\begin{array}{l}\text { Jokowi: Kalau Saya Presiden, } 2 \text { Tahun Menteri Tak Capai Target Langsung Dicopot! } \\
\text { Jokowi: If I were the president, the minister who has not achieved the target in two years will } \\
\text { be replaced }\end{array}$ \\
\hline & $\begin{array}{l}\text { Jokowi: Kalau Mau Enak, Saya Bisa di Kantor Ber-AC Saja Tidak ke Lapangan } \\
\text { Jokowi: If I just want comfort, I can just stay in the air-conditioned office, not going to the field }\end{array}$ \\
\hline 3 July 2014 & $\begin{array}{l}\text { Anies Baswedan: Tak Terbukti Jokowi Bonekanya Megawati } \\
\text { Anies Baswedan: It is not proven that Jokowi is Megawati's puppet }\end{array}$ \\
\hline
\end{tabular}

There are four points reported by detik.com about Jokowi during the presidential campaign period. The first, in table 1, the news is about Jokowi's personality which is a populist, hard worker, honest, fair, assertive, religious, patient, open-minded, easy-going, etc. detik.com is trying to construct Jokowi's personal positive image in the public which Jokowi is populist leader that very close with the society especially lower class. He is a simple person that very understand and care with the people's interest because he was from low economic family and knows how to live in the poor condition.

Research Article - This article was checked by iThenticate 
Hence, he is nicknamed as a servant leadership that readily serve the people if he becomes the president of Indonesia and even he will spend the time more to the field instead of in the office because by coming to the people he can know the condition of the people that can become an input for his policy in the future. The news also constructs that Jokowi is not a puppet and controlled by the elites or Megawati Soekartnoputri, the founder of the Indonesia Democratic Party of Struggle (PDIP). He is a clean and trusteeship leader that does not have any black report since he became the mayor of Solo region for two period and governor of Jakarta for 2 years. He stated not sharing the chair in the house of representative (DPR) for political leaders that have already support him as a president and he will be firm if there are ministers who are unable to achieve a target within two years.

Table 2. The news discourses about Jokowi's campaign promises, activities and "blusukan"

\begin{tabular}{|c|c|}
\hline Date & News in detik.com \\
\hline 5 June 2014 & $\begin{array}{l}\text { kampanye di papua, pdip yakin jokowi bisa berikan keadilan } \\
\text { Campaigning in Papua, PDIP believes Jokowi can provide justice }\end{array}$ \\
\hline & $\begin{array}{l}\text { Kunjungi Pasar Prahara Sentani Papua, Jokowi Borong Ubi } \\
\text { Visiting Prahara Sentani Papua Market, Jokowi bought lot of sweet potatoes }\end{array}$ \\
\hline 7 June 2014 & $\begin{array}{l}\text { Blusukan ke Pasar Kebon Kembang Bogor, Jokowi Beli Tomat dan Gantungan Baju } \\
\text { Visiting Kebon Kembang Bogor Market, Jokowi bought tomatoes and hangers }\end{array}$ \\
\hline 8 June 2014 & $\begin{array}{l}\text { Mengintip Kampanye Kreatif Mobil Digital Blusukan Jokowi } \\
\text { Peeking at Jokowi's digital car creative campaign }\end{array}$ \\
\hline 13 June 2014 & $\begin{array}{l}\text { Blusukan ke Sawah di Cilacap, Jokowi Janjikan Pupuk Murah ke Petani } \\
\text { Visiting rice fields in Cilacap, Jokowi promised cheap fertilizers to farmers }\end{array}$ \\
\hline 15 June 2014 & $\begin{array}{l}\text { Jokowi Ingin Alihkan Subsidi BBM ke Pendidikan } \\
\text { Jokowi wants to divert fuel subsidies to education }\end{array}$ \\
\hline & $\begin{array}{l}\text { Jika Memungkinkan, Jokowi Akan Renegosiasi Kontrak-kontrak Karya } \\
\text { If possible, Jokowi will renegotiate work contracts }\end{array}$ \\
\hline & $\begin{array}{l}\text { Jokowi: Harus Ada Hambatan Buat Bank Asing Agar Tak Mudah Masuk RI } \\
\text { Jokowi: There must be obstacles for foreign banks so that it is not easy to enter Indonesia }\end{array}$ \\
\hline 16 June 2014 & $\begin{array}{l}\text { Kunjungi Pasar Induk Cibitung, Jokowi Keliling Naik Motor Sayur } \\
\text { Visiting Cibitung Main Market, Jokowi went around on a motorbike that carried vegetables }\end{array}$ \\
\hline & $\begin{array}{l}\text { Visi Jokowi Soal Subsidi BBM untuk Rakyat Kecil } \\
\text { Jokowi's vision of fuel subsidies for the grass root }\end{array}$ \\
\hline 19 June 2014 & $\begin{array}{l}\text { Janji Jokowi untuk Guru Honorer } \\
\text { Jokowi's promise for honorary teachers }\end{array}$ \\
\hline & $\begin{array}{l}\text { Di Sektor Kelautan, Jokowi Janjikan Sentra Produksi sampai Pesawat Tanpa Awak } \\
\text { In the marine sector, Jokowi promised production centers to unmanned aircraft }\end{array}$ \\
\hline 24 June 2014 & $\begin{array}{l}\text { Jokowi: Kalau Ekonomi Tumbuh di Atas } 7 \text { Persen, Beli Indosat Tidak Sulit } \\
\text { If the economy grows above } 7 \text { percent, buying Indosat is not difficult }\end{array}$ \\
\hline 3 July 2014 & Jika Terpilih, Jokowi Disebut Akan Membongkar Kasus Century \\
\hline
\end{tabular}

Research Article - This article was checked by iThenticate 
The second, in table 2, the news is about Jokowi's campaign promises, activities and 'blusukan' as a populist political communication. detik.com was attempting to increase the popularity of Jokowi by giving the information to the public about the activities of Jokowi's blusukan. The words of blusukan are much time that mentioned in the news. The blusukan activities are one of Jokowi's political strategies in the presidential campaign in order to gain the vote from the people especially for the lower-class. It could be seen in the news that Jokowi was very concern and care for the small trader in the market, street vendors, fishermen, farmers, and so on. He also gave promises as a political communication to the people by baying back indosat company, giving oil and gas fuel subsidies for lower-class, equitable development in Papua, giving smart Indonesian cards and so on. Most of the headlines of the news about the Jokowis's blusukan and populist political communication can increase the popularity of Jokowi's image in the public and can gain votes and supporters from the people.

Table 3. The news discourses about the support from volunteers, various level and profession for Jokowi

\begin{tabular}{|c|c|}
\hline Date & News in detik.com \\
\hline 5 June 2014 & $\begin{array}{l}\text { Sejumlah tki dukung jokowi-jk } \\
\text { A number of Indonesian workers abroad support Jokowi-JK }\end{array}$ \\
\hline 6 June 2014 & $\begin{array}{l}\text { Paguyuban Mbak Jamu Gendong Dukung Jokowi-JK } \\
\text { The Herbal Medicine Association support Jokowi-JK }\end{array}$ \\
\hline 11 June 2014 & $\begin{array}{l}\text { Jusuf Kalla: Tim Nomor Satu Diisi Elit, Kita Didukung Ribuan Relawan } \\
\text { Another team is filled with elites, we are supported by thousands of volunteers }\end{array}$ \\
\hline & $\begin{array}{l}50 \text { Musisi dan Public Figure Dukung Revolusi Mental Jokowi-JK } \\
50 \text { musicians and public figures support Jokowi-JK's mental revolution }\end{array}$ \\
\hline 12 June 2014 & $\begin{array}{l}\text { Pemuda NU Deklarasikan Dukungan untuk Jokowi - JK } \\
\text { The NU youth declared support for Jokowi-JK }\end{array}$ \\
\hline 16 June 2014 & $\begin{array}{l}\text { Jokowi Ditunggu Ribuan Kiai Kampung di Karawang } \\
\text { Jokowi is awaited by thousands of village religious leader in Karawang }\end{array}$ \\
\hline & $\begin{array}{l}\text { Sumbangan untuk Jokowi-JK Capai Rp } 54 \text { Miliar } \\
\text { Donations for Jokowi-JK reached IDR } 54 \text { billion }\end{array}$ \\
\hline 21 June 2014 & $\begin{array}{l}\text { Rakyat Tak Mudah Digoyah Black Campaign, Dukungan ke Jokowi Terus Mengalir } \\
\text { The people are not easily swayed by the Black Campaign, support for Jokowi flows endlessly }\end{array}$ \\
\hline & $\begin{array}{l}\text { Penyandang Tuna Rungu Dukung Jokowi } \\
\text { Deaf people support Jokowi }\end{array}$ \\
\hline 25 June 2014 & $\begin{array}{l}\text { Dukungan untuk Jokowi-JK Terus Mengalir } \\
\text { Support for Jokowi-JK flows endlessly }\end{array}$ \\
\hline 30 June 2014 & $\begin{array}{l}\text { Relawan Matahari Indonesia Gelar Rakornas Menangkan Jokowi-JK } \\
\text { Matahari Indonesia volunteers hold National Coordination Meeting to win Jokowi-JK }\end{array}$ \\
\hline & Organisasi Sayap Gerindra Deklarasi Dukung Jokowi-JK \\
\hline
\end{tabular}

Research Article - This article was checked by iThenticate 


\begin{tabular}{|l|l|}
\hline & The Gerindra Wing Organization declared to support Jokowi-JK \\
\hline
\end{tabular}

The third, in the table 3, detik.com was trying to constructs the readers' mind that Jokowi is the presidential candidate which supported by a number of various groups such as artist, entrepreneurs, street vendors, drivers, Indonesian workers abroad, students, peasants, customary heads, Kyai (Javanese expert in Islam), community. Detik.com also constructs the readers that Jokowi supported by many volunteers. Even the volunteers collect the money until 54 billion Rupiah to help finance the Jokowi campaign. The volunteers were not coming from the parties or structural in an organization that support Jokowi but most of them were coming from ordinary people and even mostly from middle and small people. The news about the support from any various groups for Jokowi is the most exposed news by detik.com during the campaign period.

Table 4. The news discourse about the survey and polls of Jokowi

\begin{tabular}{|c|c|}
\hline Date & News in detik.com \\
\hline 5 June 2014 & $\begin{array}{l}\text { Survei Kalangan Muslim Kota: Jokowi-JK 38,8\% vs Prabowo-Hatta 29,0\% } \\
\text { Survey: Muslim urban circles: Jokowi-JK 38.8\% vs Prabowo-Hatta 29.0\% }\end{array}$ \\
\hline & $\begin{array}{l}\text { Elektabilitas Jokowi-JK Tembus } 42,65 \% \text {, Prabowo } 28,35 \% \\
\text { Jokowi-JK electability reaches } 42.65 \% \text {, Prabowo } 28.35 \%\end{array}$ \\
\hline 10 June 2014 & $\begin{array}{l}\text { Elektabilitas Jokowi-JK Turun, Timses Yakin Bakal Naik Lagi } \\
\text { Jokowi-JK electability is down, the success team is sure it will go up again }\end{array}$ \\
\hline & $\begin{array}{l}\text { Cyrus: Elektabilitas Prabowo-Hatta 41,1\%, Jokowi-JK 53,6\% } \\
\text { Cyrus: Electability of Prabowo-Hatta 41.1\%, Jokowi-JK 53.6\% }\end{array}$ \\
\hline 15 June 2014 & $\begin{array}{l}\text { Survei Pol Tracking: Jokowi-JK 48,5\%, Prabowo-Hatta 41,1\% } \\
\text { Pol Tracking Survey: Jokowi-JK 48.5\%, Prabowo-Hatta 41.1\% }\end{array}$ \\
\hline 17 June 2014 & $\begin{array}{l}\text { Elektabilitas Jokowi Unggul 13,5\%, Wasekjen PKB: Masyarakat Punya Hati } \\
\text { Jokowi's electability is } 13.5 \% \text { ahead, PKB Deputy Secretary General: People have hearts }\end{array}$ \\
\hline 21 June 2014 & $\begin{array}{l}\text { Survei Kompas: Jokowi-JK 42,3\%, Prabowo-Hatta 35,3\% } \\
\text { Kompas Survey: Jokowi-JK 42.3\%, Prabowo-Hatta 35.3\% }\end{array}$ \\
\hline 25 June 2014 & $\begin{array}{l}\text { Survei IFES dan LSI: Elektabilitas Jokowi 43\%, Prabowo 39\% } \\
\text { IFES and LSI Survey: Jokowi's electability 43\%, Prabowo 39\% }\end{array}$ \\
\hline 26 June 2014 & $\begin{array}{l}\text { Survei LIPI: Elektabilitas Jokowi-JK 43\%, Prabowo-Hatta 34\% } \\
\text { LIPI survey: Jokowi-JK electability 43\%, Prabowo } 34 \%\end{array}$ \\
\hline 27 June 2014 & $\begin{array}{l}\text { Jokowi-JK Unggul di Survei LIPI dan LSI, Hasto: Masyarakat Ingin Perubahan } \\
\text { Jokowi-JK excels in LIPI and LSI surveys, Hasto: People want change }\end{array}$ \\
\hline 30 June 2014 & $\begin{array}{l}\text { Survei Roy Morgan: Jokowi-JK 52\%, Prabowo-Hatta 48\% } \\
\text { Roy Morgan Survey: Jokowi-JK 52\%, Prabowo-Hatta 48\% }\end{array}$ \\
\hline
\end{tabular}

The fourth, in table 4, on the first date of the campaign until at the end of the campaign period, detik.com tended to give positive information to the readers about Jokowi's electability and popularity by survey and poll from any different institutions. The total of the news, only one tended a little bit negative like 'Elektabilitas Jokowi-JK Turun, Timses Yakin Bakal Naik Lagi (Jokowi-JK's electability were going down, the successful team believed it would increase again)". The news is negative in the first sentence

Research Article - This article was checked by iThenticate 
but in the second sentence, it turned to be positive because although Jokowi's and Jusuf Kalla's electability was going down, their successful team believed that the electability would increase again.

\section{CONCLUSION}

Although media and politics both have different functions in democracies, yet they have influence and need each other in many aspects. Even both maybe can conflict. In the context of democracy, particularly in the general elections, media utilize the politicians as their news source for production which will later become the 'food' for the citizens. On the other hand, politicians need media to be known as political candidates in the eye's citizens through which they can gain vote that will later bring victory for them. For the citizens, they can consume information about the candidate's figure through the media. The function of the media in terms of politics, range themselves to one of the political candidates due to the intervention of the media organizations or ownerships. If the media organizations have personal political interests and the politicians do, it is going to be a synthesis that possibly produces the news in the sense of being biased. Here, the media is the most important that might determine the victory of the political candidate in the future.

The political image of candidates in the election campaign has become a strategy in political communication. This seems to be a leading political communication in Europe and the US as well as Indonesia. The campaigns mostly formed around the capabilities and charisma of the leaders which during the process make the leader a heroic movie star who may also have extraordinary skills. Yet after the new media technologies, it seems easier to manage the creatşon process of a leader as these digital technologies allow the content producers to more play on the leaders' visibility as editing and manipulating both the news about and the visuals.

These allowances on the social media courses in terms of public opinion are commonly referred to as agenda-setting, framing, and priming. Studies have consistently confirmed that voters are far more interested in candidate characteristics than in specific issues and are more likely to vote based on the candidate's image and even it can also affect party popularity. Hence, the political candidate and party that supports its candidate in the political arena consider news to be one of the most important tools to influence public opinion. In turn, the media or media organization sets the burning issues related to the political candidates whether in mass media or new media in the aim to influence what the public thinks. The media can be able to change the political candidate image from an outsider to be an important person in the public's eye. The advance of new technologies and the internet are one of the factors that make the news easily spread out. Only by phone the citizens can access the information about political candidates and re-produce the news into social media which makes a benefit for political candidates to gain more followers and even the political candidates become the media darling that always appears in the media.

In Indonesia, one of the phenomena of the relationship between media and politics could be seen in the presidential election in 2014. Detik.com as an online media site tended to construct Jokowi's political image positively in the headline news such as his good populist personality, campaign and blusukan activities, survey, and polls to lift Jokowi's image during the presidential campaign. We could see from the data above from table 1 to table 4 that detik.com exposed the news about Jokowi's positive side more than his negative side. The essence of media should be pure and never be influenced by any organization or authority interests. Media must keep its neutrality and independency as the mediator between citizens and politicians in the political campaign.

\section{REFERENCES}

Adam, A. (2018, February Friday). 8 Konglongmerat Media di Indonesia Via Jalur Media TV\&Cetak. Retrieved from Tirto.id: https://tirto.id/8-konglomerat-media-di-indonesia-via-jalur-media-tv-ampcetak-cEv7

Research Article - This article was checked by iThenticate

Copyright (C) The Turkish Online Journal of Design, Art and Communication 
Aji, N. (2018). Behind The Jokowi's Victory: Did Economic Voting Matter In The 2014 Indonesian Presidential Election? Research Gate, 1-11.

Alexa. (2018, December Tuesday). How Popular is detik.com? Retrieved from Alexa.com: https://www.alexa.com/siteinfo/detik.com

APJII. (2017). Penetrasi \& Perilaku Pengguna Internet Indonesia. Teknopreneur, 1-39.

Asher, R.E \& Simpson, J. M. Y. (1994). The encyclopedia of language and linguistics. Oxford: Pergamon Press.

Aspinall, E. (2015). Oligarchic Populism: Prabowo Subianto's Challenge to Indonesian Democracy. Southeast Asia Program Publications At Cornell University, 1-28.

Aspinall, E., \& Mietzner, M. (2014). Indonesian Politics in 2014: Democracy's Close Call. Routledge Taylor \& Francis Group, 347-369.

Asyari, R. (2015). Indonesian Television Journalists' Perspective On News Bias And Media Owner Intervention During Indonesia's 2014 Presidential Election. University of Sheffield, 1-5.

Balbi, G. (2015). Old And New Media. Theorizing Their Relationship In Media Historiography. Herbert Von Halem Verlag, 231-249.

Barner , M. (2011). Media And Politics. In G. Lozanov, \& O. Spassov, Media And Politics (p. 4). Sofia: Foundation Media Democracy .

BBC. (2014, July Tuesday). KPU Tetapkan Jokowi Menang di Pilpres. Retrieved from bbc.com: https://www.bbc.com/indonesia/berita_indonesia/2014/07/140722_kpu_hasil_pilpres

Cambaridge, D. (2018, December Tuesday). Meaning of New Media in the English Dictionary. Retrieved from Dictionary.cambridge.org: https://dictionary.cambridge.org/dictionary/english/newmedia

Coronel, S. S. (2003). The Role of The Media in Deepening Democracy. NGO Media Outreach, 1-23.

Craig, G. (2004). The Media, Politics and Public Life. Australia: Allen \& Unwin Academic.

Danesi, M. (2013). Encyclopedia of Media and Communication. Canada: University of Toronto Press.

Dhani, R., Lee, T., \& Fitch, K. (2015). Political Public Relations in Indonesia: A History of Propaganda And Democracy. Asia Pacific Public Relations Journal, 23-36.

Dijk, T. A. (2015). Critical Discourse Analysis. In D. Tannen, H. Hamilton, \& D. Schiffrin, The Handbook of Discourse Analysis (pp. 466-486). Chichester: Blackwell Publishers.

Dimitrova, D., Nord, L., \& Stromback, J. (2014). The Effects of Digital Media on Political Knowledge And Participation in Election Campaigns: Evidence From Panel Data. Reseach Gate, 95-118.

Dumitrescu, D., \& Mughan, A. (2010). Mass Media and Democratic Politics. In K. T. Leicht, \& J. C. Jenkins, Handbook of Politics: State and Society in Global Perspective (pp. 477-493). London: Springer.

Ekstrom, M. (2017). Research On Media And Democracy: Reflections On Changes And Challenges. Research Gate, p.45.

Fortunato , J. A., \& Martin, S. E. (2017). The Intersection Of Agenda-Setting, The Media Environment, And Election Campaign Laws. Penn State University Perss, 129-153.

Gazali, E. (2009). Political Communication In Indonesia: Media Performance In Three Eras. Research Gate, 112-149.

Hamid, A. (2014). Jokowi's Populism in the 2012 Jakarta Gubernatorial Election. Journal of Current Southasian Affairs, 85-109.

Hara, A. E. (2018). Populism In Indonesia And Its Threats to Democracy. Atlantis Press, 106-111.

Research Article - This article was checked by iThenticate 
Jamil, S. (2018). Politics In A Digital Age: The Impact of New Media Technologies on Public Participation And Political Campaign in Pakistan's 2018 Election- A Case Study of Karachi. Global Media Journal, 1-9.

Johansson, A. C. (2016). Social Media And Politics in Indonesia. Stockholm China Economic Research Institute, 1-44.

Kakiailatu, T. (2007). Media in Indonesia: Forum for political change and Critical Assessment. Asia Pacific Viewpoint, 60-71.

Khosravinik, M. (2017). Right Wing Populism In The West : Social Media Discourse And Echo Chambers. Research Gate, 53-68.

Kutseva, G. (2011). New Realities: 'Mediatization' of Politics or 'Politicization'of Media Content. In G. Lozanov, \& O. Spassov, Media And Politics (pp. 147-162). Sofia: Foundation Media Democracy.

Lister, M., Dovey, J., Giddings, S., Grant, I., \& Kelly, K. (2003). New Media: a critical Introduction. Abingdon: Routledge Taylor \& Francis Group.

Menkominfo. (2018, January Monday). Menkominfo: Baru 100 Portal Berita Online Terverifikasi. Retrieved from Kominfo.go.id: https://kominfo.go.id/content/detail/12345/menkominfo-baru-100portal-berita-online-terverifikasi/0/berita_satker

Mietzner, M. (2014). Indonesia's 2014 Election: How Jokowi Won And Democracy Survived. Journal of Democracy, 111-125.

Morgenthau, H. J. (1948). Politics Among Nations: The Struggle for Power and Peace. Alfred A. Knopf, $13-21$.

Morissan. (2017). The Influence of Politicians on Television Content in Post-Authoritarian Indonesia. Jurnal Ilmu Sosial Dan Ilmu Politik Universitas Gajah Mada, 204-220.

Mukrimin, M. (2013). The Influence of Mass Media In Political Change In Indonesia. Politika: Jurnal Ilmu Politik Universitas Diponegoro, 57-67.

Mukrimin, M. (2013). The Influence Of Mass Media In Political Change in Indonesia. Politika: Jurnal Ilmu Politik Universitas Diponegoro, 57-67.

Nugroho, Y., Putri, D. A., \& Laksmi, S. (2012). Mapping The Landscape of The Media Industry in Contemporary Indonesia. Research collaboration of Center For Innovation Policy and Governance and HIVOS Regional Office Southeast Asia, Funded by Ford Foundation, 1-4.

Nugroho, Y., Putri, D. A., \& Laksmi, S. (2012). Mapping The Landscape of The Media Industry In Contemporary Indonesia. Research collaboration of Center For Innovation Policy and Governance and HIVOS Regional Office Southeast Asia, Funded by Ford Foundation, 81-98. Retrieved from P.86

Nugroho, Y., Putri, D. A., \& Laksmi, S. (2012). Mapping The Landscape Of The Media Industry In Contemporary Indonesia. Research collaboration of Center For Innovation Policy and Governance and HIVOS Regional Office Southeast Asia, Funded by Ford Foundation, 81-98.

Pahdepie, F. (2015). Media As The Battleground For Politics: The Relations Between Politicians And Media Barons In Indonesia Politics. International Journal of Nusantara Islam, 1-10.

Perbawani, P. S., Rahayu, \& Anshari, I. N. (2018). Online Political Participation And Netizen Anonymity In Indonesia's Digital Democracy. PCD Journal, 185-212.

Peters, G. (2004). Politics Is About Governing. In A. Leftwich, What Is Politics: The Activity And Its Study (pp. 23-41). UK: Polity Press.

Prabawati, V. A. (2017, March Friday). Kunci Keberhasilan Detik.com Sebagai Media Online Nasional Terbesar. Retrieved from Dictio.id: https://www.dictio.id/t/kunci-keberhasilan-detik-com-sebagaimedia-online-nasional-terbesar/7075 
Prokurat, S. (2014). Indonesian parliamentary and presidential elections in 2014. The electoral. Research Gate, 197-210.

Putra, G. E. (2014). Bingkai Media Terhadap Pemberitaan Capres Jokowi Pada Pilpres 2014. University of Diponegoro, 1-10.

Stats, I. W. (2017, December Monday). Top 20 Countries In Internet Users Vs. Rest of The World. Retrieved from Internetworldstats.com: https://www.internetworldstats.com/top20.htm

Strömberg, D. (2015). Media And Politics. The Annual Review of Economics, 173-205.

Susilo, D. (2017). Facing The Indonesian Media Conglomeration: Action of Preservation on Political Interest. Research Gate, 42-49.

Tapsell, R. (2015). Indonesia's Media Oligarchy And The Jokowi Phenomenon. Southeast Asia Program Publications at Cornell University, 29-50.

van Dijk, T. A. (1988). Discourse analysis in society. London: Academic Press Inc.

Willis, J. (2007). Politicians and Journalists: A Symbiotic Relationship. In J. Willis, The Media Effect: How the News Influences Politics and Government (pp. 93-105). London: Praeger Publishers.

Willis, J. (2007). The Media as the Fourth Estate. In J. Willis, The Media Effects: How The News Influences Politics And Governments (pp. 137-147). London: Praeger Publishers.

Willis, J. (2007). The Media Effect: How The News Influence Politics And Government. London: Praeger publishers.

Zaller, J. (1999). A Theory of Media Politics. University of Chicago Press, 1-5. 